\title{
Peningkatan Kompetensi Pedagogik Guru SDN 38 Sungai Limau dalam Menyusun RPP Melalui Workshop Penyusunan RPP pada Kegiatan KKG Mini SDN 38 Sungai Limau Kabupaten Padang Pariaman
}

\section{Nursina}

Abstrak

Penelitian ini bertujuan untuk mengetahui: (a) Pengaruh workshop penyusunan RPP pada kegiatan KKG Mini SDN 38 Sungai Limau kabupatenPadang Pariaman dalam meningkatkan kompetensi pedagogik guru SDN 38 Sungai Limau dalam menyusun RPP. (b) Aktivitas guruguru SDN 38 Sungai limau dalam menyusun RPP selama kegiatan KKG penyusunan RPP pada kegiatan KKG. Masalah penelitian dirumuskan sebagai berikut: a) Bagaimana guru SDN 38 Sungai Limau dalam mempersiapkan penyusunan RPP selama workshop penyusunan RPP pada kegiatan KKG kabupaten Padang Pariaman? b) Bagaimana guru SDN 38 Sungai Limau dalam melaksanakan proses penyusunan RPP selama workshop penyusunan RPP pada kegiatan KKG mini SDN 38 Sungai Limau kabupaten Padang Pariaman? c) Kendala apa yang ditemukan guru SDN 38 Sungai limau dalam proses penyusunan RPP yang lengkap dan sistematis selama workshop penyusunan RPP pada kegiatan KKG Mini SDN 38 Sungai Limau? Subjek penelitian ini adalah guru-guru SDN yang berada dalam naungan SDN 38 Sungai Limau Kecamatan Sungai Limau Kabupaten Padang Pariaman yang terdiri dari 9 orang. Hasil penelitian mengenai Peningkatan Kompetensi Pedagogik Guru -guru SDN 38 Sungai Limau dalam Menyusunan RPP melalui Workshop Penyusunan RPP pada Kegiatan KKG diperoleh kesimpulan sebagai berikut : (a) Terjadi peningkatan kompetensi pedagogik Guru SDN 38 Sungai limau dalam menyusun RPP melaluiworkshop pada kegiatan KKG (b) Aktivitas guru dalam mengikuti workshop penyusunan RPP yang lengkap dan sistematis padasikluskedualebih baik daripada pada saat siklus kesatu

Kata Kunci: Kompetensi Pedagogik, Workshop

Copyright (C) 2016 IICET (Padang - Indonesia) - All Rights Reserved Indonesian Institute for Counseling, Education and Theraphy (IICET)

\section{PENDAHULUAN}

Pendidikan adalah upaya yang secara sadar dirancang untuk membantu seseorang atau sekelompok orang dalam mengembangkan ilmu pengetahuan, pandangan hidup, sikap hidup, dan keterampilan hidup baik yang bersifat manual individual maupun sosial (Sagala, 2006 : 1). Upaya sadar untuk mengembangkan kepribadian dan kemampuan siswa tersebut dapat diselenggarakan dalam berbagai bentuk. Ada yang diselenggarakan secara sengaja, terencana, terarah dan sistematis seperti pada pendidikan formal, ada yang diselenggarakan secara sengaja, akan tetapi tidak terencana dan tidak sistematis seperti yang terjadi di lingkungan keluarga (pendidikan informal), dan ada yang diselenggarakan secara sengaja dan berencana, di luar lingkungan keluarga dan lembaga pendidikan formal, yaitu melalui pendidikan non formal.

Apapun bentuk penyelenggarannya, secara umum pendidikan bertujuan untuk membantu anak-anak atau peserta didik mencapai kedewasaannya masing-masing, sehingga mereka mampu berdiri di lingkungan masyarakatnya. Untuk masyarakat kita, sesuai dengan Undang-Undang Republik Indonesia Nomor 20 Tahun 2003 Tentang Sistem Pendidikan Nasional, pasal 3, pendidikan berfungsi dan bertujuan sebagai berikut:Pendidikan nasional berfungsi mengembangkan kemampuan dan membentuk watak serta peradaban bangsa yang bermartabat dalam rangka mencerdaskan kehidupan bangsa, bertujuan untuk berkembangnya potensi peserta didik agar menjadi manusia yang beriman dan bertakwa kepada Tuhan Yang Maha Esa, berakhlak mulia, sehat, berilmu, cakap, kreatif, mandiri, dan menjadi warga negara yang demokratis serta bertanggung jawab.

Agar pendidikan bisa berfungsi dan mencapai tujuan seperti dirumuskan dalam undang-undang tersebut, maka pendidikan harus "diadministrasikan", atau dikelola dengan mengikuti ilmu administrasi. Yang paling sederhana, administrasi menurut Henry Fayol diartikan sebagai fungsi dalam organisasi yang unsur- 
unsurnya adalah perencanaan (planning), pengorganisasian (organizing), pemberian perintah (commanding), pengkoordinasian (coordinating), dan pengawasan (controlling) (Sagala, $2006: 23$ ).

Pada level ujung tombak pendidikan, yaitu pada proses pembelajaran oleh guru di kelas, betapapun administrasinya tidak serumit oraganisasi yang melibatkan banyak personal, fungsi-fungsi administrasi yang disebutkan Henry Fayol tersebut sebaiknya tetap ada, sebab tanpa itu pencapaian tujuan pembelajaran akan susah dicapai. Dalam kaitannnya dengan fungsi-fungsi administrasi ini, lebih spesifik dalam hal proses belajar mengajar, Gage dan Berliner dalam Makmun (2005 : 23) mengemukakan tiga fungsi atau peran guru dalam proses tersebut, yaitu sebagai :

1) Perencana (planner) yang harus mempersiapkan apa yang harus dilakukan di dalam proses belajarmengajar (pre-teaching problems).

2) Pelaksana (organizer) yang harus menciptakan situasi, memimpin, merangsang, menggerakkan, dan mengarahkan kegiatan belajar mengajar sesuai dengan rencana, bertindak sebagai nara sumber (source person), konsultan kepemimpinan (leader), yang bijaksana dalam arti demokratis dan humanistik (manusiawi) selama proses berlangsung (during teaching problems).

3) Penilai (evaluator) yang harus mengumpulkan, menganalisis, menafsirkan dan akhirnya harus memberikan pertimbangan (judgement) atas tingkat keberhasilan belajar mengajar tersebut berdasarkan kriteria yang ditetapkan baik mengenai aspek keefektifan prosesnya, maupun kualifikasi produk (output)-nya.

Dalam menyoroti salah satu peran guru dalam proses pembelajaran, yaitu sebagai perencana pembelajaran, setiap guru pada satuan pendidikan, termasuk guru Seni Budaya SMA berkewajiban menyusun RPP yang lengkap dan sistematis agar pembelajaran efektif dan bermutu. Pembelajaran yang berlangsung secara efektif dan bermutu akan berimplikasi pada peningkatan mutu proses dan hasil belajar peserta didik.

Guru-guru SDN 38 Sungai Limau telah menyusun RPP sesuai dengan kompetensi dasar (KD) mata pelajaran tersebut. Namun masih ditemukan berbagai kekurangan baik menyangkut persiapan sebelum penyusunan RPP, dalam penyusunan RPP, maupun dalam pelaksanaan pembelajarannya.

Kondisi yang demikian menjadikan persepsi guru SDN 38 Sungai Limau mengenai RPP yang harus disusunnya sebelum melaksanakan pembelajaran di kelas, studio atau tempat belajar lainnya menjadi beragam dan kurang komprehensif. Misalnya masih terdapat guru yang belum memahami komponen minimal RPP, apalagi mengenai RPP yang komponennya lengkap dan sistematis. Kekurangan ini tentu saja akan menghambat upaya peningkatan mutu proses dan hasil pembelajaran Seni Budaya, karena RPP-nya tidak disusun dengan baik. Padahal, keberhasilan sebuah kegiatan, lebih dari 50\% ditentukan oleh perencanaan yang baik, sehingga keberhasilan pembelajaran pun amat ditentukan oleh RPP yang disusun guru.

Hasil dari penelitian ini bermanfaat untuk mengembangkan ilmu manajemen pendidikan, khususnya manajemen (pengelolaan) pembelajaran di SDN 38 Sungai Limau Manfaat praktis dari hasil penelitian ini adalah untuk meningkatkan kompetensi pedagogik guru SDN 38 Sungai Limau dalam menyusun RPP yang lengkap dan sistematis, sehinggaRPP yang mereka susun :

1) Menjadi pedoman atau skenario pelaksanaan proses pembelajaran yang bisa diikuti atau dilaksanakan siapa pun pemerannya, seandainya guru yang menyusunnya sendiri berhalangan hadir saat pelaksanaan pembelajaran

2) Memudahkan peserta didik dalam belajar dan meningkatkan prestasi belajarnya.

3) Meningkatkan kompetensi pedagogik guru dalam penyusunan RPP

4) Meningkatkan nilai kinerja sekolah dan nilai akreditasi sekolah.

\section{METODOLOGI PENELITIAN}

Metode yang digunakan dalam penelitian ini adalah metode Penelitian Tindakan Sekolah (PTS). Penelitian tindakan sekolah merupakan:

a. penelitian partisipatoris yang menekankan pada tindakan dan refleksi berdasarkan

b. pertimbangan rasional dan logis untuk melakukan perbaikan terhadap suatu kondisi nyata

c. memperdalam pemahaman terhadap tindakan yang dilakukan

d. memperbaiki situasi dan kondisi sekolah / pembelajaran secara praktis" (Depdiknas, 2008:11).

Secara singkat, PTS bertujuan untuk mencari pemecahan permasalahan nyata yang terjadi di sekolahsekolah, sekaligus mencari jawaban ilmiah bagaimana masalah-masalah tersebut bisa dipecahkan melalui suatu tindakan perbaikan. Lokasi penelitian dalam penelitian ini adalah guru-guru 38 Sungai Limau Kecamatan sungai limau yang berlokasi di Desa Durian Daun ,kecamatan Sungai Limau

Masalah nyata yang ditemukan di sekolah, khususnya pada guru -guru SDN 38 Sungai Limau Kecamatan Sungai Limau kabupaten Padang Pariaman adalah belum optimalnya guru guru dalam menyusun RPP. Prosedur penelitiannya dilakukan secara siklikal. Satu siklus dimulai dari (1) perencanaan awal, (2) pelaksanaan, (3) observasi dan (4) refleksi. 
Subjek penelitian ini adalah guru-guru SDN yang berada dalam naungan SDN 38 Sungai Limau Kecamatan Sungai Limau Kabupaten Padang Pariaman yang terdiri dari 9 orang.

Dalam penelitian ini instrumen yang digunakan untuk mengumpulkan data adalah lembar observasi berupa rubrik, yang terdiri dari :

a. Rubrik Penilaian Rencana Pelaksanaan Pembelajaran (RPP), dimuat pada Lampiran A.

b. Rubrik Penilaian Aktivitas Guru dalam Persiapan Penyusunan Rencana Pelaksanaan Pembelajaran (RPP) selama Workshop Penyusunan RPP pada Kegiatan KKG

c. Rubrik Penilaian Aktivitas Guru dalam Proses Penyusunan Rencana Pelaksanaan Pembelajaran (RPP) selama Workshop Penyusunan RPP pada Kegiatan KKG.

d. Pedoman Wawancara (Diskusi) Untuk Mengetahui Kendala yang Ditemukan Guru selama Workshop Penyusunan RPP pada Kegiatan KKG.

Rubrik ini diisi oleh peneliti melalui pangamatan sebelum, pada saat, dan sesudah proses penyusunan RPP. Hasilnya digunakan untuk menentukan tindakan selanjutnya.

Teknik Pengumpulan Data

a. Observasi

Observasi adalah semua kegiatan yang dilakukan untuk mengamati, merekam, dan mendokumentasikan setiap indikator dari proses dan hasil yang dicapai. Dalam observasi ini peneliti menggunakan

1) Rubrik Penilaian Rencana Pelaksanaan Pembelajaran (RPP),

2) Rubrik Penilaian Aktivitas Guru dalam Persiapan Penyusunan Rencana Pelaksanaan Pembelajaran (RPP) selama Workshop Penyusunan RPP pada Kegiatan KKG

3) Rubrik Penilaian Aktivitas Guru dalam Proses Penyusunan Rencana Pelaksanaan Pembelajaran (RPP) selama Workshop Penyusunan RPP pada Kegiatan KKG

b. Wawancara (Diskusi)

Yang dimaksud wawancara di sini meliputi diskusi formal dan dialog informal selama berlangsungnya PTS antara peneliti dengan guru-guru yang berada dalam gugus III Sungai Limau dalam kegiatan KKG . Hal ini untuk mengetahui pikiran guru-guru yang tidak dapat digali melalui observasi.

c. Studi Dokumenter

Studi dokumenter diartikan sebagai usaha untuk memperoleh data dengan jalan menelaah catatancatatan yang disimpan sebagai dokumen atau files. Teknik ini ditempuh untuk memperoleh data-data mengenai Rancangan Pelaksanaan Pembelajaran (RPP) guru -guru kelas dari lembaran-lembaran RPP buatan guru.

d. Studi Pustaka

Studi pustaka diartikan sebagai teknik untuk memperoleh data atau informasi dari berbagai tulisan ilmiah baik cetak maupun elektronik yang menunjang penelitian. Teknik ini ditempuh untuk memperoleh pengetahuan yang mendalam mengenai masalah yang diteliti, terutama dalam menentukan arah, metoda dan landasan teoritis penelitian.

\section{HASIL DAN PEMBAHASAN PENELITIAN \\ Hasil Penelitian \\ Siklus I}

Pencentangan nilai didasarkan pada jumlah peserta yang mencantumkan aspek yang dinilai. Katagori nilai didasarkan pada nilai total yang diperoleh dari hasil perkalian jumlah aspek yang dicentang dari suatu nilai dengan nilai. Karena terdapat 40 aspek, maka nilai total mínimum : 40 × $1=40$, dan nilai total maksimum : 40 × $4=160$

Berdasarkan hasil observasi pelaksanaan tindakan perbaikan pada siklus kesatu, masih ada beberapa hal yang perlu diperbaiki, yaitu:

a. Guru kesulitan menentukan kegiatan pembelajaran yang dilakukan secara sistematis, meliputi

1) Kegiatan Pembelajaran Pendahuluan : orientasi, apersepsi, motivasi, pemberian acuan, dan pembagiankelompok belajar,

2) Kegiatan Pembelajaran Inti: eksplorasi, elaborasi, dan konfirmasi,dan

3) Kegiatan Pembelajaran Penutup: mengarahkan peserta didik membuat kesimpulan, memeriksa hasil belajar, dan memberikan arahan tindak lanjut.

b. Guru kesulitan menentukan metode pembelajaran yang disesuaikan dengan situasi dan kondisipesertadidik, serta karakteristik dari setiap indikator dan kompetensi yang hendak dicapai.

c. Guru kesulitan membagi kegiatan pembelajaran menjadi beberapa pertemuan untuk RPP dari KD yang membutuhkan materi pembelajaran yang luas, sehingga cenderung dirancang untuk satu pertemuan. 
d. Guru masih kesulitan membedakan antara bentuk evaluasi (penilaian) proses dan hasil belajardenganformat / lembaran butir soal-soal dalam komponen Evaluasi (Penilaian) Proses dan Hasil Pembelajaran.

e. Guru menemukan adanya peluang menambah komponen RPP, dan beberapa guru telah menambahkannya menurut pendapat mereka.

Hasil observasi melalui Rubrik Penilaian Rencana Pelaksanaan Pembelajaran (RPP), nilainya mencapai nilai 119, yang berarti berada pada katagori baik. Hasil observasi melalui Rubrik Penilaian Aktivitas Guru dalam Menyusun Rencana PelaksanaanPembelajaran (RPP) selama Kegiatan KKG, nilainya mencapai nilai 30, yang beratiberadapada katagori baik. Dengan masih terdapatnya hal-hal tersebut di atas, maka diperlukan langkah perbaikan selanjutnya. Dengan kata lain perlu siklus kedua sehingga perbaikannya optimal.

\section{Siklus II} refleksi.

Dalam siklus kedua pun dilakukan rangkaian kegiatan perencanaan, pelaksanaan, observasi, dan

a. Perencanaan Untuk menyusun rencana pada siklus kedua, peneliti melakukan:

1) Mempersiapkan instrumen penelitian berupa

a) Rubrik Penilaian Rencana Pelaksanaan Pembelajaran(RPP) dan

b) Rubrik Penilaian Aktivitas Guru Seni Budaya SMA dalam Persiapan Penyusunan RencanaPelaksanaan Pembelajaran (RPP) selama Workshop Penyusunan RPP pada kegiatan KKG,

c) Rubrik Penilaian Aktivitas Guru dalam Proses Penyusunan Rencana Pelaksanaan Pembelajaran (RPP) selama Workshop Penyusunan RPP pada Kegiatan KKG, dan

d) Pedoman Wawancara (Diskusi) Untuk MengetahuKendala yang Ditemukan Guru kelas selama Workshop Penyusunan RPP pada Kegiatan.

e) Membawa hasil refleksi pada siklus kesatu kepada guru-guru untuk mendiskusikan kendala yang dihadapi guru dalam menyusun RPP dan cara mengatasinya sebelum pelaksanaan kegiatan penyusunan RPP yang lengkap dan sistematis pada tindakan perbaikan sikluskedua dimulai.

Hasilnya adalah sebagai berikut:

a) Guru-guru meminta peneliti menempatkan diri sebagai nara sumber untuk menjelaskan caramenentukan kegiatan eksplorasi, elaborasi, dan konfirmasi dalam komponen Kegiatan PembelajaranInti,

b) menjelaskan komponen-komponen apa saja yang cocok untuk ditambahkan ke dalam RPP sehingga menjadi lengkap dan sistematis, dan

c) penilaian (evaluasi) proses dan hasil pembelajaran.

d) RPP dirancang lengkap dan sistematis. Komponen dalam RPP tidak saja mengandung komponen RPP minimal, tapi ditambah komponen lain yang dipandang diperlukan untuk membuat RPP yang lengkap dan sistematis, sehingga dari lima komponen minimal menjadi 11 komponen yang lengkap.

e) RPP disusun guru bersama peneliti yang menempatkan diri sebagai nara sumber.

Sesuai dengan kesepakatan yang telah diputuskan oleh peneliti dan guru pada hari hari Sabtu tanggal 23 Juli 2014 guru-guru dan peneliti bersama-sama melaksanakan kegiatan penyusunan RPP yang lengkap dan sistematis. Kegiatan diawali dengan pemberian penjelasan oleh peneliti yang menjadi nara sumber mengenai cara menentukan kegiatan eksplorasi, elaborasi, dan konfirmasi dalam komponen Kegiatan Pembeljaran Inti, komponen-komponen yang bisa ditambahkan ke dalam komponen RPP minimal, dan evaluasi proses dan hasil pembelajaran.

Bersamaan dengan berlangsungnya pelaksanaan kegiatan penyusunan RPP Seni Budaya oleh guru, peneliti melakukan observasi dengan menggunakan

1) Rubrik Penilaian Aktivitas Guru dalam Persiapan Penyusunan Rencana Pelaksanaan Pembelajaran (RPP) selama Workshop Penyusunan RPP pada Kegiatan KKG

2) Rubrik Penilaian Aktivitas Guru Seni Budaya SMA dalam Proses Penyusunan Rencana Pelaksanaan Pembelajaran (RPP) selama Workshop Penyusunan RPP pada Kegiatan KKG

3) Rubrik Penilaian Rencana Pelaksanaan Pembelajaran (RPP).

Hasil Penilaian melalui Rubrik Penilaian Aktivitas Guru Seni Budaya SMA dalam Persiapan Penyusunan Rencana Pelaksanaan Pembelajaran (RPP) selama Workshop Penyusunan RPP pada Kegiatan KKG pada Siklus II. Rubrik Penilaian Aktivitas Guru Seni Budaya SMA dalam Proses Penyusunan Rencana Pelaksanaan Pembelajaran (RPP) selama Workshop Penyusunan RPP pada Kegiatan KKG pada siklus II. Hasil Penilaian melalui Rubrik Penilaian Rencana Pelaksanaan Pembelajaran (RPP) pada Siklus II

Berdasarkan hasil observasi pelaksanaan tindakan kedua, ditemukan bahwa: 
1) Guru mencantumkan komponen Identitas dengan segala rinciannya dengan benar.

2) Guru mencantumkan standar kompetensi (SK) yang sesuai dengan standar isi dan silabus.

3) Guru mencantumkan kompetensi dasar (KD) yang sesuai dengan standar isi dan silabus.

4) Guru mencantumkan komponen Indikator Pencapaian dengan rumusan kalimat yang mengandung kata kerja operasional yang terukur sebagai penjabaran kompetensi dasar, dan sesuai dengan materi pembelajaran.

5) Guru mencantumkan komponen Tujuan Pembelajaran dengan kalimat yang mencantumkan subyek belajar (learner), target yang dicapai siswa, dan relevan dengan kompetensi dasar (KD)

6) Guru mencantumkan komponen Materi Pembelajaran dengan rincian yang sistematis, sesuai dengan tujuan pembelajaran (TP) dan standar isi, dan telah mencantumkan materi pembelajaran untuk pengayaan.

7) Guru mencantumkan komponen Kegiatan Pembelajaran, membaginya kedalam Kegiatan Pembelajaran Pendahuluan, Kegiatan Pembelajaran Inti dan Kegiatan Pembelajaran Penutup. Setiap bagian dirinci menjadi kegiatan pembelajaran yang student centered, disertai alokasi waktu tiap kegiatan siswa.

8) Guru mencantumkan komponen Metoda / Model Pembelajaran yang disatukan secara sistematis dengan komponen Kegiatan Pembelajaran.

9) Guru dapat mencantumkan komponen Media / Sumber Pembelajaran dengan menentukan jenis sumber belajarnya sesuai dengan tuntutan kurikulum (kompetensi dasar dan silabus), tujuan pembelajaran, dan bentuk evaluasi.

10) Guru mencantumkan komponen Penilaian (Evaluasi) Proses dan Hasil Pembelajaran, dan merincinya dengan lengkap, dari mulai bentuk evaluasi, menyertakan lembaran / format instrumen penilaian (butir soal, rubrik, dll.), pedoman penilaian, dan kunci jawabannya.

11) Hasil observasi melalui Rubrik Penilaian Rencana Pelaksanaan Pembelajaran (RPP), nilainya mencapai nilai 151, yang berarti berada pada katagori sangat baik.

Hasil observasi melalui Rubrik Penilaian Aktivitas Guru dalam Menyusun Rencana Pelaksanaan Pembelajaran (RPP) selama Kegiatan KKG, nilainya mencapai nilai 36, yang berati berada pada katagori sangat baik.

\section{Pembahasan}

Dalam kegiatan orientasi, ditemukan bahwa dalam RPP guru kelas yang dibuat guru memiliki banyak kekurangan. Dari segi sistematika, RPP yang mereka susun tidak terlalu mengganggu. Mereka sudah bisa menempatkan sub-sub komponen atau isi komponen RPP pada komponen yang tepat. Namun dari segi kelengkapan, RPP yang mereka susun masih terbatas pada RPP dengan komponen yang minimal ditambah beberapa komponen, namun tetap kurang lengkap. Bahkan beberapa guru tidak mencantumkan komponen Tujuan Pembelajaran, karena merasa sudah tersirat pada komponen Indikator Pencapaian. Kemudian, betapapun komponen Kegiatan Pembelajaran, dan komponen Evaluasi (Penilaian) Proses dan Hasil Pembelajaran dicantumkan, namun isi dari kedua komponen tersebut kurang rinci, sehingga bagaimana guru membuka pembelajaran, bagaimana guru menutup pembelajaran, mengevaluasi dan menindaklanjuti hasil belajar siswa kurang jelas.

Mengetahui adanya komponen RPP minimal yang tidak dicantumkan dan tidak rincinya isi beberapa komponen RPP, maka dasar-dasar rujukan dalam penyusunan RPP dipersiapkan dan dikaji guru, sehingga mereka menemukan bukti rujukan mengenai apa-apa yang harus ada dalam RPP. Dasar-dasar rujukan yang berupa permendiknas dan buku-buku yang relevan tersebut dipergunakan dalam pelaksanaan tindakan perbaikan pada siklus kesatu. Pada tindakan perbaikan siklus kesatu ini, guru -guru menyususn RPP dengan mengacu kepada dasar-dasar rujukan penyusunan RPP, terutama:

1. PP 19 Tahun 2005 tentang Standar Nasional Pendidikan pasal 20, bahwa "Perencanaan proses pembelajaran meliputi silabus dan rencana pelaksanaan pembelajaran yang memuat sekurangkurangnya tujuan pembelajaran materi ajar, metode pengajaran, sumber belajar, dan penilaian hasil belajar".

2. Permen Nomor 41 Tahun 2007 tentang Standar Proses yang menyatakan bahwa RPP harus dijabarkan dari silabus untuk mengarahkan kegiatan belajar peserta didik dalam upaya mencapai kompeiensi dasar, dan setiap guru pada satuan pendidikan berkewajiban menyusun RPP yang lengkap dan sistematis agar pembelajaran berlangsung secara interaktif, inspiratif, menyenangkan, menantang, memotivasi peserta didik untuk berpartisipasi aktif, serta memberi ruang yang cukup bagi prakarsa, kreativitas, dan kemandirian sesuai dengan bakat, minat, dan perkembangan fisik, serta psikologis peserta didik. 


\section{KESIMPULAN DAN SARAN \\ Kesimpulan}

Berdasarkan hasil penelitian mengenai Peningkatan Kompetensi Pedagogik Guru -guru SDN 38 Sungai Limau dalam Menyusunan RPP melalui Workshop Penyusunan RPP pada Kegiatan KKG , diperoleh kesimpulan sebagai berikut :

a. Terjadi peningkatan kompetensi pedagogik Guru SDN 38 Sungai limau dalam menyusun RPP melaluiworkshop pada kegiatan KKG

b. Aktivitas guru dalam mengikuti workshop penyusunan RPP yang lengkap dan sistematis pada siklus kedua lebih baik daripada pada saat siklus kesatu.

\section{Saran}

Berdasarkan kesimpulan yang diperoleh dari penelitian tindakan sekolah ini, penulis menyarankan:

a. Guru-guru SDN 38 Sungai Limau, diharapkan agar mengoptimalkan perannya sebagai perencana, pengorganisir, dan penilai pembelajaran yang handal, sehingga pembelajaran dapat berjalan lebih efektif.

b. Kepada Kepala sekolah yang berada di gugus III diharapkan agar memfasilitasi guru-guru yang jadi bawahannya untuk aktif dalam kegiatan KKG guna meningkatkan kompetensi pedagogiknya, termasuk dalam penyusunan RPP mata pelajaran yang diampunya. Kemampuan pedagogik yang meningkat akan berimbas pada peningkatan mutu pendidikan di sekolah.

a) Kepada Dinas Pendidikan Kabupaten Padang Pariaman diharapkan agar dapat memfasilitasi kegiatan KKG, gua meningkatkan mutu pendidikan di SDN 38 Sungai Limau.

\section{DAFTAR PUSTAKA}

BSNP. (2007). Peraturan Menteri Pendidikan Nasional Republik Indonesia Nomor 16 Tahun 2007 Tentang Standar Kualifikasi Akademik dan Kompetensi Guru. Jakarta: BSNP.

Depdiknas. (2003). Revitalisasi Musyawarah Guru Mata Pelajaran (MGMP). Jakarta: Program Pendidikan Menengah Umum.

Makmun, Abin Syamsudin. (2005). Psikologi Kependidikan, Perangkat Sistem Pengajaran Modul. Bandung: PT. Remaja Rosdakarya.

Peraturan Menteri Pendidikan Nasional Republik Indonesia Nomor 41 Tahun 2007 Tentang Standar Proses untuk Satuan Pendidikan Dasar dan Menengah.

Peraturan Pemerintah Nomor 19 Tahun 2005 tentang Standar Nasional Pendidikan.

Sagala, H. Syaiful. (2006). Administrasi Pendidikan Kontemporer. Bandung: Alfabeta.

Sudjana, H. Nana. (2009). Penelitian Tindakan Kepengawasan, Konsep dan Aplikasinya bagi Pengawas Sekolah. Jakarta: Binamitra Publishing.

Undang-Undang Republik Indonesia Nomor 14 Tahun 2005 tentang Guru dan Dosen.

Undang-Undang Republik Indonesia Nomor 20 Tahun 2003 Tentang Sistem Pendidikan Nasional.

Wardani, IGAK, dkk. ((2007). Penelitian Tindakan Kelas. Buku Materi Pokok IDIK4008/2SKS/MODUL 16. Jakarta: Universitas Terbuka 